\title{
PERANAN MBAH WO KUCING DALAM PELESTARIAN REOG DAN WAROK DI KABUPATEN PONOROGO
}

\section{Reza Adi Primawan \& Abraham Nurcahyo*}

\begin{abstract}
Abstrak
Penelitian ini bertujuan untuk mendapatkan gambaran tentang Peranan Mbah Wo Kucing dalam pelestarian Reog dan Warok di Kabupaten Ponorogo. Penelitian dilakukan di Kabupaten Ponorogo. Penelitian ini menggunakan pendekatan penelitian kualitatif dengan jenis penelitian kualitatif-deskriptif. Sumber data yang digunakan dalam penelitian ini adalah sumber data primer yang berupa informan dan sumber data sekunder yang berupa sumber pustaka, arsib, wawancara, dan pengamatan lapangan. Pengumpulan data dalam penelitian ini menggunakan tiga macam yaitu: observasi, dokumentasi, dan wawancara yang dilakukan dengan teknik purposive sampling. Validasi yang digunakan untuk menguji kebenaran data menggunakan trianggulasi sumber penelitian. Sedangkan analisis data menggunakan analisis model interaktif yang terdiri dari reduksi data, penyajian data, dan penarikan kesimpulan atau verifikasi.

Dari penelitian yang dilaksanakan diperoleh gambaran, bahwa perkembangan Reog dan Warok Ponorogo tidak lepas dari campur tangan orang-orang yang peduli terhadap keberlangsungannya. Salah satu tokoh yang giat untuk melestarikan Reog dan Warok di Kabupaten Ponorogo adalah Kasni Gunapati (Mbah Wo Kucing). Kasni Gunopati (Mbah Wo Kucing) lahirpada tanggal 30 Juni 1934 di Desa Kauman Kecamatan Kauman Kabupaten Ponorogo. Mbah Wo Kucing merupakan anak pertama dari empat bersaudara putra pasangan Martorejo dan Sutilah. Usaha Kasni Gunapati (Mbah Wo Kucing) dalam melestarikan budaya lokal Ponorogo adalah dengan mendirikan paguyuban Reog Ponorogo yang diberi nama Pujangga Anom. Paguyuban Reog Pujangga Anom berdiri pada tahun 1966 sampai Mbah Wo Kucing meninggal dunia Semasa hidup Mbah WO Kucing mendedikasikan hidupnya untuk melestarikan Kesenian Reog Ponorogo dengan cara melatih murid-muridnya agar nilai-nilai karakter dalam kesenian Reog Ponorogo selalu ada dalam hati para penerusnya. Adapun peninggalan dan bukti konkret dari sepak terjang Paguyuban Pujangga Anom yang didirikan oleh Mbah Wo Kucing adalah dua dhadak merak sekaligus kepala barongannya, satu set gong, dua kendhang, satu slompret, dan pakaian-pakain menari milik muridmurid Mbah Wo Kucing. Selain itu dalam hidupnya Mbah Wo Kucing tetap menggunakan identitas Warok Ponorogo sebagai identitas dirinya. Sebagai masyarakat asli Ponorogo istilah Warok dan sebuah paguyuban Reog tidak bisa dipisahkan. Warok merupakan seorang pelaku seni sekaligus yang membahwahi sebuah paguyuban tersebut.
\end{abstract}

Kata Kunci : Mbah Wo Kucing, Reog, Warok.

\section{Pendahuluan}

Manusia merupakan makhluk yang berbudaya, melalui akalnya manusia dapat mengembangkan kebudayaan (Elly, Kama, dan Ridwan, 2007: 37). Begitu pula manusia hidup dan bergantung pada kebudayaan sebagai hasil ciptaannya. Kesederhanaan hubungan antara manusia dan kebudayaan adalah salah satu bukti bahwa manusia merupakan makhluk berbudaya yang juga sering disebut dengan homo humanus. Hubungan tersebut yakni manusia sebagai pelaku kebudayaan dan kebudayaan merupakan obyek yang dilaksanakan manusia. Manusia menciptakan kebudayaan, dan setelah kebudayaan itu 
tercipta maka kebudayaan mengatur hidup manusia agar sesuai dengannya. Tampak bahwa keduanya akhirnya merupakan satu kesatuan. Dengan demikian manusia tidak dapat lepas dari kebudayaan karena kebudayaan itu merupakan perwujudan dari manusia itu sendiri.

Kebudayaan yang telah ada memiliki nilai estetik yang bermacammacam sesuai dengan karakteristik masingmasing seni yang ada pada jiwa kebudayaan itu. Kebudayaan dan seni juga merupakan satu kesatuan pribadi dalam sebuah bentuk keindahan yang unik sehingga ikatan antara keduanya sangat erat.

Adanya manusia, kebudayaan, dan seni akhirnya memberikan sebuah tatanan inspiratif bagi pemikirnya memunculkan sebuah kesenian yang berbudaya oleh manusia itu sendiri yang bermakna. Kesenian yang memiliki alur yang bermakna bagi penikmatnya memberikan kisah kreasi aktif manusia lainnya untuk memahami. Semua hal tersebut tentu ada permulaan dan pengembangaannya.

Rafael Raga Maran (2000: 103) berpendapat bahwa memang sulit memisahkan permulaan antara kesenian dengan permulaan kebudayaan manusia, karena aktivitas sosial, pada hakikatnya, bersifat artistik, yakni pembentukan lingkungan materil, menjadi lingkungan yang manusiawi berkat ketrampilan dan kreativitas manusia. Munculnya kebudayaan di suatu daerah cenderung tidak lepas dari pengaruh dari masyarakat yang selalu melestarikan kebudayaan itu yang berasal dari warisan turun-temurun dari nenek moyang. Perkembangan kebudayaan yang berbeda-beda di setiap daerah akan mampu menggambarkan ciri khas daerah tersebut. Ciri khas tersebut mampu mengintepretasikan bagaimana kehidupan masyarakat berkembang dari masa ke masa. Selain daripada perkembangan kebudayaan daerah tersebut, sikap dari masyarakat juga diperlukan untuk senantiasa selalu memelihara kekhasan daerah yang menjadikan identitas bagi daerah dan masyarakat tersebut.

Masyarakat adalah kesatuan hidup manusia yang berinteraksi menurut suatu sistem adat-istiadat tertentu yang bersifat kontinu, dan yang terikat oleh suatu rasa identitas bersama (Koentjaraningrat, 2009: 118). Masyarakat sebagai komponen utama dalam perkembangan kehidupan memiliki karakteristik yang salah satunya adalah menunjukan perhatian bersama secara mendasar terhadap budaya lokal. Adapun masyarakat yang melestarikan budaya lokal yang sudah ada sejak dahulu tidak semuanya mampu untuk bertahan begitu lama. Hal itu disebabkan karena pengaruh perkembangan kebudayaan modern yang begitu cepat sehingga kebanggaan akan budaya lokal sedikit demi sedikit luntur.

Setiap manusia mempunyai penilaian terhadap kebudayaan dan kesenian yang beraneka ragam baik dalam 
lingkup lokal, nasional, maupun internasional di kehidupan dunia yang mereka lihat. Di Indonesia, masing-masing propinsi mempunyai bermacam-macam kebudayaan yang berwujud kesenian asli daerah yang tersebar di pelosok kabupatenkabupaten sebagai ciri khas kebudayaan masyarakat daerah setempat.

Namun, tidak semua masyarakat meninggalkan budaya asli setempat dan beralih kepada budaya modern dengan diikuti oleh perkembangan pesat di bidang teknologi. Salah satu yang akan dibahas dalam skripsi ini adalah sosok seniman Reyog Ponorogo dan budayawan yang berasal dari Kabupaten Ponorogo, beliau adalah Mbah Wo Kucing.

Kabupaten Ponorogo merupakan salah satu kabupaten yang terletak di propinsi Jawa Timur. Letak geografis Kabupaten Ponorogo sendiri diapit oleh 2 gunung besar di Jawa Timur yaitu gunung Wilis di sebelah timur dan gunung Lawu di sebelah barat. Adapun Kabupaten Ponorogo sendiri berbatasan dengan Kabupaten Madiun di sebelah utara, Kabupaten Pacitan di sebelah selatan, Kabupaten Wonogiri dan Kabupaten Magetan di sebelah barat, dan Kabupaten Trenggalek di sebelah timur. Seperti di banyak daerah lain di Indonesia, Kabupaten Ponorogo memiliki budaya lokal yang tentunya berasal dari warisan nenek moyang dan menjadi sebuah kebanggaan bagi masyarakatnya. Salah satu budaya lokal yang sampai sekarang masih terus dilestarikan dan dikembangkan adalah kesenian Reyog Ponorogo.

Kesenian Reyog Ponorogo adalah kesenian khas Kabupaten Ponorogo yang menjadi identitas masyarakat Kabupaten Ponorogo. Kesenian ini pula merupakan kesenian asli kebanggaan Indonesia yang sampai sekarang menjadi primadona yang harus dilestarikan keberadaannya. Nilai adalah sesuatu yang baik yang selalu diinginkan, dicita-citakan, dan dianggap penting oleh seluruh manusia sebagai anggota masyarakat (Elly, 2007: 31).

Nilai yang terkandung dalam kesenian Reyog Ponorogo inilah yang dianggap penting oleh masyarakat untuk selalu dilestarikan. Oleh sebab itu sebagian kecil dari masyarakat berusaha untuk melestarikan kesenian Reyog Ponorogo ini agar tidak tergerus oleh arus globalisasi yang mengikis budaya lokal setempat. Beberapa diantara masyarakat tersebut adalah kelompok seniman. Para seniman ini meyakini bahwa dengan melestarikan kesenian Reyog Ponorogo, mereka mampu melestarikan tradisi yang sudah ada sejak lama di Kabupaten Ponorogo ini untuk terus hidup dan berkembang.

Dalam perkembangan dan upaya pelestarian budaya lokal Kabupaten Ponorogo yang terwujud dalam kesenian Reyog Ponorogo ini banyak masyarakat Kabupaten Ponorogo yang belum mengetahui pelaku pelestari kesenian Reyog Ponorogo yang selalu masyarakat 
lihat ketika memperingati hari jadi Kabupaten Ponorogo yang sering diadakan Festival Reyog Mini dan peringatan grebeg suro yang diperingati dengan diadakannya Festival Reyog Nasional (FRN).

Salah satu pelestari budaya lokal yang berwujud kesenian Reyog Ponorogo adalah Mbah Wo Kucing. Sampai saat ini pun masyarakat belum mengetahui secara jelas profil dan peranan dari Mbah Wo Kucing sebagai salah satu sesepuh pelestari kesenian Reyog Ponorogo dan budaya lokal Ponorogo yang menjadi identitas dan kebanggaan Kabupaten Ponorogo. Mbah Wo Kucing sangat dihormati di kalangan seniman Reyog Ponorogo di Kabupaten Ponorogo. Banyak sekali seniman-seniman muda yang menimba ilmu dan pengalaman dalam upaya untuk melestarikan budaya lokal Ponorogo yang tergambar dalam kesenian Reyog Ponorogo dan Warok sebagai identitas asli dan khas dari masyarakat Ponorogo.

\section{Kajian Pustaka}

\section{A. Peranan}

Peranan adalah proses memahami perilaku yang diharapkan yang berkaitan dengan kedudukan seseorang (Anidal et al, 1984: 55). Selain pendapat diatas, pengertian peranan adalah bagian dari tugas utama yang harus dilaksanakan (Bambang Marhijanto, 1995: 460). Tidak jauh beda dengan pendapat di atas, Soerjono
Soekanto (2012: 212) juga menjelaskan bahwa peranan (role) adalah aspek dinamisi kedudukan (status). Apabila seseorang melaksanakan hak dan kewajibannya sesuai dengan kedudukannya, dia menjalankan suatu peranan. Pembedaan antara kedudukan dengan peranan adalah untuk kepentingan ilmu pengetahuan. Keduanya tidak dapat dipisah-pisahkan karena yang satu tergantung pada yang lain atau sebaliknya.

Berdasarkan pendapat tentang pengertian peranan di atas maka dapat didefinisikan bahwa peranan adalah perilaku yang diharapkan yang berkaitan dengan kedudukan seseorang sebagai bagian dari tugas utama yang harus dilaksanakan. Setiap orang mempunyai macam-macam peranan yang berasal dari pola-pola pergaulan hidupnya.

hal itu sekaligus berarti bahwa peranan menentukan apa yang diperbuatnya bagi masyarakat serta kesempatan-kesempatan apa yang diberikan oleh masyarakat kepadanya. Pentingnya peranan adalah karena ia mengatur perilaku seseorang. Peranan menyebabkan seseorang pada batasbatas tertentu dapat meramalkan perbuatan-perbuatan orang lain (Soerjono, 2012: 213)

Soerjono (2007:

menjelaskan bahwa peranan mungkin mencakup tiga hal, yaitu pertama 
peranan meliputi norma-norma yang dihubungkan dengan posisi atau tempat seseorang dalam masyarakat. Peran dalam arti ini merupakan rangkaian peraturan-peraturan yang membimbing seseorang dalam kehidupan kemasyarakatan. Kedua, peran merupakan suatu konsep tentang apa yang dapat dilakukan oleh individu dalam masyarakat sebagai organisasi. Ketiga, peranan juga dapat dikatakan sebagai perilaku individu yang penting bagi struktur sosial masyarakat.

Fasilitas peranan (role-facilities) adalah fasilitas-fasilitas yang diberikan oleh masyarakat kepada warganya agar dapat menjalankan peranannya (Anidal et al, 1984: 17). Masyarakat biasanya memberikan fasilitas-fasilitas kepada individu untuk dapat menjalankan peranan. Lembaga-lembaga kemasyarakatan merupakan bagian masyarakat yang banyak menyediakan peluang-peluang untuk pelaksanaan peranan (Soerjono, 2012: 214).

\section{B. Pelestarian}

Penggalian budaya nasional bukan diarahkan pada konformisme budaya, tetapi lebih diarahkan pada totalitas nilai dan perilaku yang mencerminkan hasrat dan kehendak masyarakat Indonesia dalam berbangsa dan bernegara dengan dua arah pokok, yaitu fungsi pelestarian dan fungsi pengembangan. Fungsi pelestarian diarahkan pada pengenalan dan pendalaman nilai-nilai luhur budaya bangsa, sehingga diharapkan dapat menumbuhkan dan memperkokoh rasa cinta tanah air dan kebanggaan nasional (Abraham Nurcahyo et al, 2011: 151).

Pelestarian merupakan perlindungan dari kemusnahan atau kerusakan (Kamus Besar Bahasa Indonesia, 1991: 588).

Berdasarkan pengertian tersebut pelestarian adalah upaya dinamis untuk mempertahankan keberasaan cagar budaya dan nilai dengan cara melindungi, mengembangkan, dan memanfaatkannya.

\section{Kebudayaan Daerah/Lokal}

Menurut Sulasman dan Setia Gumilar (2013: 271-272) kebudayaan daerah adalah kebudayaan dalam wilayah atau daerah tertentu yang diwariskan secara turun-temurun oleh generasi terdahulu kepada generasi berikutnya pada ruang lingkup daerah tersebut. Budaya daerah ini muncul saat penduduk suatu daerah telah memiliki pola pikir dan kehidupan sosial yang sama sehingga menjadi suatu kebiasaan mereka yang membedakan mereka dengan penduduk lain. Budaya daerah mulai terlihat berkembang di Indonesia pada zaman kerajaan-kerajaan terdahulu. Hal itu dapat dilihat dari cara hidup dan interaksi sosial yang dilakukan 
masyarakat kerajaan di Indonesia yang berbeda satu sama lain.

Dari pola kegiatan ekonomi, Sulasman dan Setia (271-272) juga menjelaskan kebudayaan daerah dikelompokkan beberapa macam, yaitu kebudayaan pemburu dan peramu, kebudayaan peternak, kebudayaan peladang, kebudayaan nelayan, dan kebudayaan pedesaan.

a. Kebudayaan pemburu dan peramu kelompok kebudayaan pemburu dan peramu ini pada masa sekarang hampir tidak ada. Kelompok ini tinggal di daerah-daerah terpencil.

b. Kebudayaan peternak kelompok kebudayaan peternak/ kebudayaan berpindah-pindah banyak dijumpai di daerah padang rumput.

c. Kebudayaan peladang kelompok kebudayaan peladang hidup di daerah hutan rimba. Mereka menebang pohon-pohon, membakar ranting, daun-daun dan dahan yang ditebang. Setelah bersih, mereka menanami berbagai macam tanaman pangan. Setelah dua atau tiga kali ditanami, mereka meninggalkan lahan tersebut dan membuka ladang baru di daerah lain.

d. Kebudayaan nelayan kelompok kebudayaan nelayan ini hidup di sepanjang pantai. Desa-desa nelayan umumnya terdapat di daerah muara sungau atau teluk. Kebudayaan nelayan ditandai kemampuan teknologi pembuatan kapal, pengetahuan cara-cara berlayar di laut, pembagian kerja nelayan laut.

e. Kebudayaan petani pedesaan; kelompok kebudayaan petani pedesaan ini menduduki bagian terbesar di dunia. Masyarakat petani ini merupakan kesatuan ekonomi, sosial budaya dan administratif yang besar. Sikap hidup gotong royong mewarnai kebudayaan petani pedesaan.

Penyebutan kata Reyog dulunya adalah "Reyog". Kata Reyog berasal dari kata "riyet" atau kondisi bangunan yang rusak atau hampir rubuh. Selanjutnya pada era Bupati Markoem Singodimedjo diubah. Kata Reyog yang diubah menjadi "Reog" dikarenakan kebijakan pemerintah daerah. Kebijakan pemerintah daerah menghapuskan huruf "y" dalam Reyog ini memang didasarkan pada penelitian dalam Kamus Besar Bahasa Indonesia yang diterbitkan oleh Depdiknas pada tahun 1983 (Uswatun Hasanah, 2014: 51).

Berbeda dengan pendapat di atas, Reog diambil dari bahasa Arab (Riyyuq), karena pengaruh dari dialek bahasa jawa maka berubah menjadi kata Reog yang artinya khusnul khotimah atau bagus pada akhirnya (apik pungkasane dalam bahasa Jawa) (Riyadi dalam Maryaeni, 2008: 83). Purwowidjojo (dalam 
Maryaeni, 2008: 84) juga mengungkapkan bahwa Reog merupakan seni pertunjkan tari daerah Ponorogo. Reog mempunyai cerita khusus mengenai legendanya. Cerita ini digolongkan ke dalam folklor, yaitu suatu cerita yang berkembang dalam masyarakat secara turun-temurun tanpa adanya kejelasan tentang siapa penyampai pertamanya. Folklor sendiri lebih populer dengan sebutan ilmu gosip. Ada berbagai versi tentang asal-muasal Kesenian Reog Ponorogo (Herry Lisbijanto, 2013: 1). Secara garis besar ada tiga, yaitu:

1) Legenda versi Bantarangin yang menyebutkan empat tokoh penting dalam kesenian reog, yaitu Raja Kerajaan Bantarangin bernama Klana Sewandana, Patih Kerajaan Batarangin yang bernama Bujang Ganong, sekelompok prajurit berkuda Kerajaan Bantarangin, dan Singa Barong yang merupakan penguasa hutan Lodaya.

2) Legenda versi $\mathrm{Ki}$ Ageng Kutu Suryangalam, yang menyebutkan tiga peran utama dalam kesenian reog, yaitu Bujang Ganong, sekelompok pasukan berkuda kerajaan Bantarangin dan Singa Barong di penguasa hutan Lodaya. Dalam versi ini jumlah dan identitas peran dalam Reog Ponorogo tidak berbeda dengan versi Bantarangin.
3) Legenda versi batara Katong juga menyebut peran keempat tokoh di atas. Versi Batara Katong memahami keempat peran dalam Reog tersebut sebagai rekaan Ki Ageng Mirah, salah seorang pengikut Batara Katong dalam upayanya menyebarkan agama Islam di kalangan masyarakat Ponorogo pada abad XV, yang saat itu adalah masa-masa menjelang runtuhnya Kerajaan Majapahit.

Pengertian kesenian adalah unsur pengikat yang mempersatukan pedoman-pedoman bertindak yang berbeda menjadi suatu desain yang utuh, menyeluruh, dan operasional, serta dapat diterima sebagai sesuatu yang bernilai (Noryaan Bahari, 2008: 45). Kesenian Reog Ponorogo menurut Herry (2013: 1) adalah berupa tarian yang dimainkan sekelompok orang. Ada yang membawa dhadhak merak, pemain jathil, penabuh gamelan, dan kelompok senggakan. Mereka bermain dengan iringan gamelan dan teriakan senggakan.

Adapun jenis seni pertunjukan Reog Ponorogo menurut Uswatun (2014: 77-78,81-82) dibagi menjadi 2 yaitu kesenian Reog Obyog dan kesenian Reog dalam festival.

1) Kesenian Reog Obyog

Reog Obyogan biasanya ditanggap oleh individu, keluarga, desa, organisasi, atau kelompok masyarakat tertentu yang mengisi 
acara-acara khusus seperti pernikahan, khitanan, selametan, bersih desa atau rasulan, serta peristiwa-peristiwa penting lainnya. istilah obyogan yang disebut juga gambyongan adalah sebutan bagi salah satu bagian dari pertunjukan Reog dalam tanggapan di desa-desa yang menampilakn tarian dan penari jathil secara bebas.

Para jathil biasanya melepas jaran kepangnya, lalu menari dengan iringan musik yag bernacam-macam mulai dari jaipongan hingga dangdut, melayu, dan campursari. Pada saat obyogan atau gambyongan ini, biasanya penonton ikut berjoget (istilah yang lebih tepat daripada menari) dengan para penari jathil. Penari jathil mendapatkan posisi sentral dalam pertunjukan atau pementasan Reyog obyogan, selain barongan. Reog Obyogan dipentaskan dalam ruang yang berubah-ubah sesuai dengan situasi dan kondisi seperti di halaman rumah, pinggir jalan, perempatan jalan, tanah lapang, dan lain-lain.

2) Kesenian Reog Festival

Reog festival merupakan Reog Ponorogo versi lengkap. Reog festival mementaskan lakon cerita Kerajaan Bantarangin yang berupa cerita proses lamaran Prabu Klana Sewandana kepada Dewi Sanggalangit putri Kerajaan Kediri. Reog Festival (RF) merupakan versi Reog Ponorogo yang dilombakan/difestivalkan dengan adanya pembatasan durasi pementasan.

Reog festival dipentaskan di atas panggung yang memang disediakan untuk proses pementasan Reog festival tersebut. Adanya panggung tersebut memberikan batasan yang jelas antara pelaku seni dengan penonton, sehingga penonton tidak dapat ikut serta berjoget atau sebagai pelaku seni dadakan. Reog festival pada umumnya selalu dipentaskan pada dua hajatan besar yang dimiliki oleh Pemerintah Kabupaten Ponorogo yaitu Festival Reog Nasional (FRN) dan Festival Reog Mini Nasional (FRMN) yang diadakan satu tahun sekali oleh Dinas Kebudayaan Pariwisata Pemuda dan Olahraga Kabupaten Ponorogo.

Pementasan Reog festival selalu mengacu pada standar pementasan Reog Ponorogo Festival. Pada pementasan Reog festival dituntut untuk mengikuti standar penjurian FRN maupun FRMN. Drama tari yang dipentaskan merupakan kesatuan yang komplit mulai dari adegan tari Warok, Bujangganong, Jathil, Klana Sewandana, dan Singa Barong. Gerakan tari pada Reog festival tetap berpedoman pada 
standar gerakan tari Reog Ponorogo yang ada, walaupun diperbolehkan adanya aransemen koreografi tari.

Herry (2013: 19-21) menjelaskan bahwa Warok merupakan sesepuh dalam kesenian reog. Kedekatan mereka dengan dunia spiritual sering membuat mereka disegani masyarakat. Seorang warok konon harus menguasai apa yang disebut Reh Kamusankan Sejati, jalan kemanusiaan yang sejati. Warok adalah pasukan pembela kebenarran yang selalu memerangi kejahatan. Warok tua adalah tokoh pengayom, sedangkan Warok muda adalah Warok yang masih dalam taraf menuntut ilmu.

Warok dipersepsikan sebagai tokoh yang pemerannya harus memiliki kekuatan gaib. Bahkan beredar cerita miring tentang sosok Warok ini, terkesan jahat, garang, dan berorientasi seks sejenis. Sosok warok diidentikan dengan celana kolor, pakaian hitam-hitam, memiliki kesaktian, dan gemblakan. Tentang hal ini dijelaskan oleh sesepuh warok, Kasni Gunapati atau yang lebih dikenal sebagai Mbah Wo Kucing, bahwa warok bukanlah seorang yang takabur karena kekuatan yang dimilikinya. Warok merupakan orang yang mempunyai tekad suci, siap memberikan tuntunan dan perlindungan tanpa pamrih.

Warok berasal dari kata wewarah. Warok ialah wong kang sugih wewarah, artinya seseorang menjadi Warok karena mampu memberi petunjuk atau pengajaran kepada orang lain tentang hidup yang baik. Warok digambarkan sebagai orang yang sempurna laku hidupnya, dan sampai pengendapan batin.

Gemblak merupakan seorang anak laki-laki yang ganteng, usia dibawah lima belas tahun, berkulit kuning. Gemblak ialah profesi anak laki-laki yang dikencani oleh Warok. Upah Gemblak tahun 60-an adalah satu ekor sapi sebulan. Gemblak selalu mendampingi Warok karena Warok tidak boleh menikah dengan wanita. Karena Warok tidak boleh menikah dengan wanita maka Warok mengencani Gemblak tersebut. Larangan itu sebenarnya ditujukan kepada Warok Singa Kobra (pimpinan Reog saat itu) yang memiliki aji-aji Blorong Putih. Blorong Putih akan selalu menambah kekuatan Singa Kobra jika Singa Kobra tidak menikah. Sampai saat ini, gemblak masih ada, tetapi perannya tidak secara langsung ditonjolkan (Maryaeni, 2008: 102).

\section{Metode Penelitian}

\section{A. Tempat dan Waktu Penelitian}

Berdasarkan kajian awal dan atas dasar pertimbangan yang diambil oleh peneliti, maka objek atau Lokasi penelitian ini di Kabupaten Ponorogo, Propinsi Jawa Timur. Alasan dipilihnya lokasi ini dengan pertimbangan bahwa 
Kabupaten Ponorogo merupakan daerah tempat tinggal Mbah Wo Kucing dan tempat berkiprahnya Mbah Wo Kucing dalam melestarikan budaya-budaya yang ada di Kabupaten Ponorogo khususnya Reog dan Warok.

Waktu penelitian yang disarankan oleh peneliti adalah selama 6 bulan terhitung sejak bulan februari 2013 hingga bulan juli 2013, dipilihnya rentang waktu tersebut karena peneliti menilai dalam pengumpulan sumbersumber data serta melakukan analisi data akan lebih akurat dan objektif lagi.

\section{B. Pendekatan dan Jenis Penelitian}

Berdasarkan Penelitian yang digunakan yaitu penelitian kualitatif. Bogdan dan Guba (dalam Uhar Suharsaputra, 2012: 181) menjelaskan bahwa penelitian kualitatif atau naturalistic inquiry adalah prosedur penelitian yang menghasilkan data deskriptif berupa kata-kata tertulis atau lisan dari orang dan perilaku yang dapat diamati.

Metode yang digunakan berupa kualitatif yang disebut juga naturalistik, alamiah, dengan pertimbangan melakukan penelitian dalam latar yang sesungguhnya hingga objek tidak berubah, baik sebelum maupun sesudah diadakan suatu penelitian (Nyoman Kutha Ratna, 2010: 95). Dalam arti luas, pendekatan kualitatif adalah suatu metode menelaah mengenai esensi, mancari makna dibalik frekuensi dan variasi (Hadi Sabari Yunus, 2010: 341).

Dalam hal makna, pendekatan ini erat kaitannya dengan ciri objek yang akan diteliti.Sehingga dapat disimpulkan penelitian kualitatif adalah penelitian kualitatif lebih menekankan kepada analisisnya pada proses penyimpulan deduktif dan induktif yang ditujukan untuk mendeskripsikan dan menganalisis antar fenomena, peristiwa, dan aktivitas sosial, sikap, kepercayaan, persepsi, pemikiran orang secara individual maupun kelompok.

Jenis penelitian ini adalah penelitian deskriptif-kualitatif. Clolid Narbuko dan Abu Achmadi (2003: 45) menjelaskan bahwa penelitian deskriptif yaitu penelitian yang berusaha menuturkan pemecahan masalah yang ada sekarang berdasarkan data, jadi ia juga menyajikan data, menganalisis dan menginterpretasi.

Penelitian deskriptif bermaksud membuat pemeriaan (penyandaraan) secara sistematis, faktual, dan akurat mengenai fakta-fakta dan sifat-sifat populasi tertentu. (Husaini Usman dan Purnomo Setiady Akbar, 2004: 4).

Deskriptif-kualitatif yang akan dihasilkan yaitu mengenai peranan Mbah Wo Kucing dalam melestarikan Reog dan warok di Kabupaten Ponorogo dan pandangan masyarakat Kabupaten Ponorogo terhadap usaha-usaha Mbah 
Wo Kucing dalam melestarikan Reog dan Warok di Kabupaten Ponorogo.

\section{Sumber Data}

1. Sumber Data Primer dan Sekunder Sumber primer adalah sumber data yang langsung memberikan data kepada pengumpul data (Sugiyono, 2011: 308). Sumber data yang bersifat primer pada penelitian ini adalah masyarakat Kabupaten Ponorogo yang meliputi: Pihak DISBUDPARPORA Kabupaten Ponorogo, Seniman Reog Ponorogo, para warga sekitar kediaman Mbah Wo Kucing, dan keluarga Mbah Wo Kucing itu sendiri.

Sumber data sekunder diperoleh untuk melengkapi data primer. Data sekunder adalah data yang diperoleh dari dokumendokumen grafis (tabel, catatan, notulen rapat, SMS, dan lain-lain), foto-foto, film, rekaman video, bendabenda dan lain-lain yang dapat memperkaya data primer (Suharsimi, 2010: 22). Hal senada dijelaskan oleh Lexy J. Moleong (2007: 216-219) yang menambahkan bahwa dokumen yang diperoleh dapat berasal dari dokumen pribadi maupun dokumen resmi.

Dokumen pribadi seperti buku harian, surat pribadi dan otobiografi. Sedangkan dokumen resmi seperti memo, pengumuman, instruksi, aturan suatu lembaga masyarakat tertentu yang digunakan dalam kalangan sendiri, majalah, buletin, pernyataan, dan berita yang disiarkan kepada media massa. Peneliti dalam hal ini mengambil sumber data dari dokumen resmi maupun dokumen pribadi, antara lain foto, pernyataanpernyataan, keterangan-keterangan langsung dari saksi hidup yang mengetahui kiprah Mah Wo Kucing dalam melestarikan Reog dan Warok di Kabupaten Ponorogo dan biografi Kabupaten Ponorogo tahun 2013.

\section{Teknik Pengumpulan Data}

1. Observasi

Observasi merupakan proses yang kompleks, yang tersusun dari proses biologis dan psikologis. Dalam menggunakan teknik observasi yang terpenting adalah mengandalkan pengamatan dan ingatan si peneliti. (Husaini \& Purnomo, 2004: 54).

\begin{tabular}{llr}
\multicolumn{2}{c}{ Peneliti yang } & sedang \\
melakukan & pengamatan & tidak \\
selamanya menggunakan & panca \\
inderanya saja, tetapi & selalu \\
mengkaitkan apa yang dilihatnya \\
dengan apa yang dihasilkan oleh \\
pancaindera lainnya (Burhan Bungin, \\
2007: 115).
\end{tabular}

Observasi yang digunakan dalam penelitian ini adalah observasi non partisipasi. Peneliti cukup mengamati aktifitas masyarakat Kabupaten Ponorogo untuk 
memperoleh data yang memadai tentang riwayat hidup dan peranan Mbah Wo Kucing dalam melestarikan Reog dan Warok Ponorogo di Kabupaten Ponorogo.

2. Dokumentasi

$$
\text { Suharsimi (2010: 274) }
$$
mengemukakan metode dokumentasi sebagai upaya mencari data mengenai hal-hal atau variabel yang berupa catatan, transkrip, buku, surat kabar, majalah, notulen, agenda rapat dan sebagainya. Metode dokumentasi biasanya digunakan untuk mengumpulkan data sekunder dari sumber kelembagaan.

Dokumen yang digunakan dalam penelitian ini adalah dokumen DISBUDPARPORA Kabupaten Ponorogo dan dokumen lain yang terkait dengan peranan Mbah Wo Kucing dalam melestarikan Reog dan Warok Ponorogo di Kabupaten Ponorogo

3. Wawancara

Hadi (2010: menyampaikan bahwa wawancara adalah kegiatan pengumpulan data yang dilakukan peneliti dengan cara menanyakan secara langsung pada sumber informasi. Dalam hal ini, sumber informasi adalah penduduk yang dapat memberikan keterangan melalui media oral. Dalam wawancara pertanyaan dan jawaban diberikan secara verbal. Biasanya komunikasi ini dilakukan dalam keadaan saling berhadapan, namun komunikasi dapat juga dilaksanakan melalui telepon (Nasution, 2004: 113).

Pada wawancara ini di mungkinkan peneliti dengan informan melakukan tanya jawab secara interaktif maupun secara sepihak saja, misalnya dari peneliti saja. Dilihat dari aspek pedoman (guide) wawancara dalam proses pengambilan data, wawancara dapat dibedakan menjadi tiga macam jenis yaitu terstruktur, bebas, dan kombinasi.

Bentuk wawancara yang digunakan dalam penelitian ini adalah wawancara kombinasi yaitu perpaduan antara wawancara terstruktur dengan wawancara bebas. Maksud digunakannya wawancara kombinasi agar mendapat informasi yang semaksimal mungkin dari informan. Daftar pertanyaan dapat dimodifikasi peneliti sendiri sesuai dengan kondisi tempat dan informan yang dihadapi. Informan disini yang diwawancarai adalah Pihak DISBUDPARPORA Kabupaten Ponorogo bidang kebudayaan sebagai wakil dari Pemerintah Kabupaten Ponorogo, Seniman Reog Ponorogo, para masyarakat sekitar tempat tinggal Mbah Wo Kucing dan juga keluarga Mbah Wo Kucing itu sendiri. 


\section{E. Prosedur Penelitian}

Penulis memilih penelitian
dengan menggunakan penelitian
kualitatif, sedangkan tahap-tahap atau
prosedur yang dilakukan adalah sebagai
berikut:

1. Tahap persiapan penelitian yang menyangkut penentuan tema dan pengajuan judul, kemudian pengamatan atau observasi awal, dilakukan pada bulan Pebruari.

a. Tahap pelaksanaan penelitian dengan pengumpulan data di lapangan dan menganalisis data.

b. Pengumpulan data dilakukan dengan observasi dan wawancara. Dengan observasi, peneliti mengadakan pengamatan langsung di Kabupaten Ponorogo. Kemudian mengumpulkan dokumen dan arsip yang diperoleh dari: kepustakaan IKIP PGRI MADIUN dan kepustakaan-kepustakaan lain, DISBUDPARPORA Kabupaten Ponorogo, Perpustakaan Daerah (PERPUSDA) Kabupaten Ponorogo, dan literatur lain yang relevan. Disamping itu melakukan wawancara dengan: Pihak keluarga Mbah Wo Kucing, DISBUDPARPORA Kabupaten Ponorogo bidang kebudayaaan, seniman Reog Ponorogo Kabupaten Ponorogo, para warga sekitar tempat tinggal Mbah Kucing.

c. Melakukan analisis data yang berupa reduksi data, penyajian data, dan penarikan kesimpulan atau verifikasi. Berdasarkan semua hal yang telah direduksi dan disajikan. Apabila hasil kesimpulan yang ditulis kurang memadai, maka peneliti melakukan kegiatan ulang untuk mencari data yang dianggap penting.

2. Tahap penyelesaian yakni berupa penyusunan laporan. Peneliti menyusun laporan penelitian setelah melaksanakan semua rangkaian penelitian baik di lapangan atau setelah mendapatkan kesimpulan serta sudah lengkap untuk dibuat dalam sebuah laporan penelitian.

\section{F. Teknik Keabsahan Data}

Teknik keabsahan data atau validasi data dilakukan melalui trianggulasi. Dalam mengabsahkan data, trianggulasi diartikan sebagai teknik pengumpulan data yang bersifat menggabungkan dari berbagai teknik pengumpulan data dan sumber data yang telah ada (Sugiyono, 2011: 330). Teknik trianggulasi mendorong peneliti dalam mengembangkan suatu laporan yang akurat. Burhan (2007: 252) menjabarkan bahwa trianggulasi dapat dilakukan dengan menguji apakah proses dan hasil 
metode yang digunakan sudah berjalan baik, seperti:

1. Peneliti menggunakan wawancara mendalam dan observasi non partisipasi untuk pengumpulan data;

2. Setelah itu dilakukan uji ulang terhadap materi catatan-catatan harian itu untuk memastikan tidak ada informasi yang bertentangan antara catatan harian wawancara dan catatan harian observasi;

3. Hasil konfirmasi itu perlu diuji lagi dengan informasi-informasi sebelumnya untuk menghindari perbedaan informasi yang dihimpun sebelumnya dari informan atau sumber-sumber lain dan terakhir dilakukan konfirmasi.

Proses trianggulasi yang dilakukan akan berhenti dilakukan oleh peneliti apabila tidak ada lagi data-data yang ingin dikonfirmasi kepada informan. Uji keabsahan melalui teknik trianggulasi ini dilakukan dalam penelitian kualitatif karena menguji keabsahan informasi tidak dapat dilakukan dengan alat-alat uji statistik.

Menurut Patton (dalam H.B. Sutopo, 2006: 92), ada 4 macam trianggulasi sebagai teknik pemeriksaan untuk mencapai keabsahan data yaitu trianggulasi data, trianggulasi peneliti, trianggulasi metodologis, trianggulasi teoritis. Dalam penelitian ini peneliti menggunakan trianggulasi data.
Trianggulasi sumber juga disebut sebagai trianggulasi data. Cara ini mengarahkan peneliti agar dalam mengumpulkan data, peneliti wajib menggunakan beragam sumber yang berbeda-beda. Artinya, data yang sama atau sejenis, akan lebih mantap kebenarannya bila digali dari beberapa sumber data yang berbeda. Dengan demikian apa yang diperoleh dari sumber yang satu, bisa teruji kebenarannya jika dibandingkan dengan data sejenis yang diperoleh dari sumber lain yang berbeda.

Mengumpulkan data dari berbagai sumber data tersedia, data yang sama akan terlihat kebenarannya bila digali dari beberapa sumber data yang berbeda. Contohnya menggunakan berbagai sumber data seperti dokumen, arsip, hasil wawancara, hasil observasi atau juga dengan mewawancarai lebih dari satu subjek yang dianggap memiliki sudut pandang yang berbeda. Berikut merupakan bagan trianggulasi sumber data:

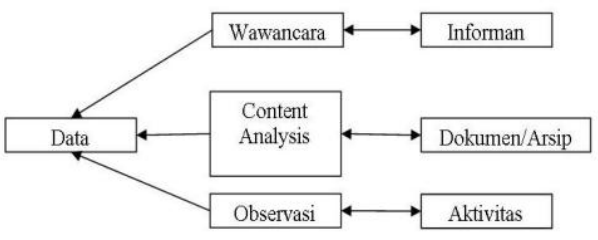

Gambar 3.1. Triangulasi Sumber oleh

Sumber: (Sutopo, 2010:80)

Jadi teknik triangulasi ini bisa menjadi jalan terbaik untuk menghilangkan segala jenis perbedaan 
pada temuan-temuan sewaktu mengumpulkan data, sehingga pemeliti bisa melakukan cek ulang dengan membandingkan berbagai sumber, metode, dan teori. Sehingga peneliti bisa mengajukan banyak pertanyaan, kemudian mengeceknya dengan berbagai sumber data, melakukan berbagai metode agar validitas data dapat dilakukan.

\section{G. Teknik Analisis Data}

Proses penyederhanaan data ke dalam bentuk yang lebih mudah dilakukan dalam reduksi data. Menurut Emzir (2011: 85), analisis data adalah proses sistematis pencarian dan pengaturan transkripsi wawancara, catatan lapangan, materi-materi lain yang telah di kumpulkan untuk meningkatkan pemahaman mengenai materi-materi tersebut dan untuk memungkinkan untuk menyajikan apa yang sudah ditemukan kepada orang lain. Kegiatan analisis melibatkan pekerjaan dengan data, penyusunan dan pemecahan kepada unit-unit yang dapat di tangani.

Mattew B. Milles dan A. Michael Huberman (1992: 16-19) membagi analisis data kualitatif terdiri atas tiga jalur kegiatan yang terjadi secara bersamaan yaitu: reduksi data, penyajian data, dan penarikan kesimpulan/verifikasi.
1. Reduksi data merupakan proses pemilihan, pemusatan, perhatian, pengabstraksian, dan penstransformasian data kasar dari lapangan. (Basrowi dan Suwardi, 2008: 209). Reduksi data berlangsung terus-menerus selama proyek yang berorientasi kualitatif berlangsung. Reduksi data merupakan bagian dari analisis data. Reduksi data merupakan suatu bentuk analisis yang menajamkan, menggolongkan, mengarahkan, membuang yang tidak perlu, dan mengorganisasi data dengan cara sedemikian rupa hingga kesimpulan-kesimpulan finalnya dapat ditarik dan diverifikasi.

2. Penyajian data merupakan bagian dari analisis tahap kedua. Merancang deretan dan kolom-kolom sebuah matriks untuk data kualitatif dan memutuskan jenis dan bentuk data yang harus dimasukkan ke dalam kotak-kotak kegiatan analitis. Milles \& Huberman (1992: 17), membatasi suatu "penyajian" sebagai sekumpulan informasi tersusun yang memberi kemungkinan adanya penarikan kesimpulan dan pengambilan tindakan. Dengan melihat penyajian-penyajian kita akan dapat memahami apa yang sedang terjadi dan apa yang harus dilakukan (lebih jauh menganalisis ataukah mengambil tindakan) berdasarkan 
atas pemahaman yang didapat dari penyajian-penyajian tersebut.

3. Penarikan kesimpulan (verifikasi) yakni, sekumpulan informasi yang tersusun memungkinkan adanya penarikan kesimpulan dan pengambilan tindakan. Penarikan kesimpulan hanyalah sebagian dari suatu kegiatan. Kesimpulan juga diverifikasi selama penelitian berlangsung.

Analisis merupakan proses dalam penelitian atau pencarian dan perencanaan secara sistematik semua data dan bahan lain yang terkumpul. Agar peneliti mengerti benar makna yang telah dikemukakan dan dapat menyajikan kepada yang lain secara jelas. Analisis data yang digunakan dalam penelitian ini adalah model analisis interaktif. Berikut adalah skema komponen-komponen analisis data model interaktif yang berlangsung dalam bentuk siklus.

\section{Hasil Penelitian}

\section{A. Tinjauan Singkat Kabupaten Ponorogo}

Kabupaten Ponorogo merupakan sebuah daerah di wilayah Propinsi Jawa Timur yang berada pada posisi 200 kilometer sebelah barat daya Ibukota Propinsi Jawa Timur, dan 800 kilometer dengan Ibukota Negara Indonesia. Letak astronomis Kabupaten Ponorogo adalah terletak pada $111^{0} 7^{\prime}$ hingga $111^{0} 52^{\prime}$ Bujur Timur dan $7^{0}$ 49' hingga $8^{0}$ 20' Lintang Selatan. Wilayah Kabupaten Ponorogo secara langsung berbatasan dengan Kabupaten Magetan, Kabupaten Madiun, dan Kabupaten Nganjuk di sebelah utara. Kabupaten Ponorogo sebelah timur berbatasan langsung dengan Kabupaten Tulungagung dan Kabupaten Trenggalek. Sebelah selatan Kabupaten Ponorogo berbatasan langsung dengan Kabupaten Pacitan. Kabupaten Ponorogo di sebelah barat berbatasan langsung dengan Kabupaten Pacitan dan Kabupaten Wonogiri (Propinsi Jawa Tengah). Wilayah Kabupaten Ponorogo 79\% terletak di ketinggian kurang dari 500 meter di atas permukaan laut, $14,4 \%$ berada di ketinggian antara 500 meter hingga 700 meter di atas permukaan laut dan sisanya $5,9 \%$ wilayah Kabupaten Ponorogo berada pada posisi di atas 700 meter dari permukaan laut. (Badan Pusat Statistik Kabupaten Ponorogo; 2013: 34).

\section{B. Riwayat Mbah Wo Kucing}

Mbah Wo Kucing adalah salah satu sesepuh seniman Reog Ponorogo sekaligus sesepuh Warok Ponorogo yang ada di Kabupaten Ponorogo. Mbah Wo Kucing memiliki nama asli yaitu Kasni Gunopati. Beliau lahir pada 30 Juni 1934 di Desa Kauman Kecamatan Kauman Kabupaten Ponorogo. Mbah Wo Kucing 
atau Kasni Gunopati merupakan anak pertama dari empat bersaudara putra dari pasangan Martorejo dan Sutilah (Wawancara dengan Kasmiati tanggal 10 April 2014).

Ciri Fisik Kasni Gunopati yaitu bertubuh tinggi kurus, memiliki kumis dan jenggot yang panjang berwarna putih, berperawakan tegap layaknya seorang Warok dan juga selalu memakai celana kombor (Kathok Kombor Maro Kentol) khas masyarakat Kabupaten Ponorogo waktu itu. Mbah Wo Kucing sering melakukan segala macam jenis puasa dan tirakat dengan cara tidak tidur beberapa hari beberapa malam karena melatih ilmu kebatinan dan ilmu kekuatan tubuh (kanuragan), serta kegiatan yang sangat padat dikarenakan beliau memiliki multiprofesi. Kasni Gunopati atau Mbah Wo Kucing memiliki badan kurus namun kekuatan fisik beliau diatas rata-rata orang biasa, hal itu disebabkan karena Kasni Gunopati dahulu adalah pemain sepak bola dan sering menjaga kesehatan tubuh dengan berolahraga.

Berbanding lurus dengan ciri fisiknya, Kasni Gunopati juga mempunyai ciri kepribadian yang sangat berwibawa dihormati oleh semua orang yang bertemu dengan beliau, mengayomi keluarga dan masyarakat sekitar, selalu menjalankan tirakat untuk mencapai tingkat tertinggi dalam spiritualnya, selalu berbicara jujur, tidak suka berbohong, kalem dan ramah kepada siapa saja, bersahaja, dan sebagai sesepuh dan pini sepuh Desa Kauman, Kasni Gunopati adalah pengayom masyarakat dan menjadi tokoh penengah apabila terdapat konflik.

Semasa kecil dan remaja Kasni Gunopati menempuh pendidikan setara dengan sekolah dasar yang waktu itu dikelola oleh Belanda. Lulus dari sekolah tersebut Kasni Gunopati mulai tertarik dengan dunia seni utamanya seni Reog Ponorogo yang dahulu masih sangat eksis dikalangan masyarakat Kabupaten Ponorogo. Hal itu disebabkan karena sebagian masyarakat Kabupaten Ponorogo khususnya lingkungan keluarga Kasni Gunopati yang belum mengenal arti penting tentang pendidikan, maka kehidupan remaja Kasni Gunopati dihabiskan untuk membantu orang tua menjadi petani, menjadi mandor tebu untuk membantu perekonomian keluarga, menyekolahkan adik-adiknya, membantu perekonomian keluarga, mencari pengalaman tentang ilmu kanuragan dan kebatinan ke berbagai daerah di Jawa Timur, Jawa Tengah dan Yogyakarta, mempelajari bagaimana melestarikan Reog Ponorogo dengan mendirikan sebuah paguyupan Reog Ponorogo, serta menjadi pemain sepak bola untuk menunjang kekuatan fisik dan ketahanan tubuh bahkan 
sampai ke pertandingan tingkat Propinsi Jawa Timur. Dari bermain bola itulah Kasni Gunapati remaja memperoleh uang untuk membantu perekonomian keluarga.

Memasuki usia dewasa Kasni Gunopati atau Mbah Wo Kucing ditunjuk menjadi perangkat Desa Kauman. akhirnya Kasni Gunopati diangkat sebagai Kamituwo Desa Kauman Kecamatan Kauman Kabupaten Ponorogo yang ditunjuk langsung oleh Lurah Desa Kauman pada waktu itu. Semenjak saat itulah maka nama Kasni Gunopati terdapat kependekan kata "Wo" yang berasal dari kependekan kata Kamituwo. Mbah Wo Kucing menjadi Kamituwo antara tahun 1956-1995.

Memasuki usia yang sudah cukup untuk berkeluarga, Kasni Gunopati akhirnya menikah. Pada pernikahan pertama karena berbagai hal, Kasni Gunopati harus bercerai dengan istrinya dan mempunyai satu anak. Beberapa lama kemudian Kasni Gunopati bertemu dengan Kasmiati yang saat itu merupakan janda berumur 24 Tahun memiliki satu anak yang tidak lain adalah tetangga beliau, dan pada 9 Juni 1966 Mbah Wo Kucing menikah untuk kedua kalinya dan pernikahan dengan Kasmiati, Kasni Gunopati dikaruniai tiga orang anak. Berturut-turut anak-anak Kasni Gunopati dari pernikahan sebelumnya dan pernikahan dengan Kasmiati adalah
Siti Nurjanah, Ismini, Rumanah, Trianawati, dan Gatot Hariyanto.

Semua sifat dan sikap yang dimiliki oleh Mbah Wo Kucing juga tidak semuanya bisa untuk ditiru. Mbah Wo Kucing dulu ketika masih muda memiliki kegemaran berjudi, bermain sepak bola, dan sering berkumpul dengan para Warok Ponorogo yang lain dalam suatu acara diberbagai tempat. Menurut cerita yang berkembang pada masyarakat sekitar tempat tinggal Kasni Gunopati dan para teman seangkatan maupun seprofesi dengan beliau sebagai seniman Reog Ponorogo, istilah "Kucing" yang tersemat pada Kasni Gunopati atau Mbah Wo Kucing merujuk pada sifat seekor kucing yang sangat gesit dan sangat sulit untuk ditangkap. Kasni Gunopati bermain judi, apabila terjadi penggrebegkan oleh aparat keamanan, beliau sangat sulit untuk ditangkap dan bahkan tidak ada yang berani menangkapnya.

Selain itu ketika beliau sedang bermain kartu remi, dalam suatu suasana beliau mengatakan, "Iki mesti kucing!!!" sambil membanting kartunya dan selalu kartu yang dibanting itu sesuai dengan keinginannya sehingga Mbah Wo sering menang dalam permainan. Dengan julukan Mbah Wo Kucing inilah yang membuat Kasni Gunapati lebih terkenal namanya karena mudah diingat oleh masyarakat. Namun Kasni Gunapati tidak 
pernah sekalipun bermain judi di sekitar tempat tinggalnya.

Pada awal tahun 2008 Mbah Wo Kucing mengalami penurunan kondisi akibat usia yang sudah menginjak 73 tahun menyebabkan Mbah Wo Kucing mengidap penyakit paru-paru. Kegemaran beliau selama masih hidup dari mulai remaja sampai usia tua untuk selalu begadang malam untuk melatih ilmu dan berpuasa (tirakat), merokok, dan sering memakai pakaian terbuka menyebabkan beliau jatuh sakit. Pada hari Rabu Pon tanggal 13 Agustus 2008 Mbah Wo Kucing menghembuskan nafas terakhirnya dan meninggal dunia.

\section{Peranan Mbah Wo Kucing Dalam Pelestarian Reog dan Warok Ponorogo}

Kesenian Reog Ponorogo merupakan salah satu kesenian khas yang berasal dari Kabupaten Ponorogo. Kesenian Ponorogo identik dengan seni pertunjukan tari kolosal yang menggambarkan legenda Kerajaan Bantarangin yang dipimpin oleh Prabu Klonosewandono dan Kerajaan Kediri. Singkat cerita Prabu Klonosewandono akan mempersunting Dewi Songgolangit atau Dewi Kilisuci yang berasal dari Kerajaan Kediri yang merupakan putri keturunan Prabu Airlangga.

Awal mula Mbah Wo Kucing terjun menjadi seorang seniman Reog Ponorogo ketika Mbah Wo Kucing benar- benar ingin memulai semua hal tentang pelestarian kesenian Reog Ponorogo mulai dari titik nol. Pada tahun 19561965 dimana Mbah Wo Kucing memiliki pekerjaan sebagai perangkat desa sebagai Kamituwo dan mandor perkebunan tebu di Kecamatan Sukorejo, Kecamatan Sampung, dan Kecamatan Kauman. Pada saat yang sama Mbah Wo Kucing mulai memiliki fikiran dan niat untuk melestarikan kesenian Reog Ponorogo agar tidak dilupakan oleh masyarakat Kabupaten Ponorogo.

Perjalanan untuk melestarikan kesenian Reog Ponorogo dilakukannya sedikit-demi sedikit dengan cara menyisihkan beberapa penghasilan dari tanah bengkok gaji sebagai perangakat Desa Kauman yaitu Kamituwo dan gaji menjadi Mandor perkebunan tebu yang membawahi tiga Kecamatan di Kabupaten Ponorogo. Biaya hasil dari menyisihkan penghasilannya beliau gunakan untuk membeli perlengkapan alat musik karawitan kesenian Reog Ponorogo secara bertahap.

Usaha untuk melestarikan kesenian Reog Ponorogo tersebut maka Mbah Wo Kucing membeli alat musik untuk paguyuban Reog Ponorogo miliknya yaitu dengan membeli barongan beserta dhadak merak sejumlah satu buah. Beberapa bulan kemudian Mbah Wo Kucing membeli kendang sekaligus ketipung atau 
kendang terusan. Mbah Wo Kucing kemudian membeli slompret (terompet), angklung, dan kenong.

Pada tahun 1965 Mbah Wo Kucing mampu membeli satu dhadak merak lagi sekaligus membeli Gong yang berasal dari hasil mengumpulkan uang sedikit-demi sedikit. Perlengkapan untuk kesenian Reog Ponorogo sudah lengkap, kemudian beliau mencari seseorang yang nantinya akan ditugaskan untuk merawat seluruh perlengkapan Reog Ponorogo tersebut sehingga bisa awet dan tahan lama. Mbah Wo Kucing menunjuk seseorang pemuda di Desa Kauman yang bernama Daman. Daman adalah seorang remaja pada waktu itu yang tinggal di Desa Kauman dan selalu bersama-sama Mbah Wo Kucing sebagai asisten.

Memasuki tahun 1966 dimulailah usaha Mbah Wo Kucing untuk melestarikan Kesenian Reog Ponorogo di Desa Kauman. Paguyuban tersebut diberi nama Pujangga Anom. Pemilihan nama Pujangga Anom sendiri tidak lepas dari tokoh legenda Kerajaan Bantarangin yaitu Pujangga Anom yang merupakan pengawal setia Prabu Klono Sewandono dan memiliki kelebihan di bidang seni. Mbah Wo Kucing turun langsung ke rumah-rumah masyarakat Desa Kauman untuk memperkenalkan paguyuban tersebut supaya banyak anak-anak di
Desa Kauman yang tertarik untuk mempelajari Kesenian Reog Ponorogo.

Usaha yang tak kenal lelah yang dilakukan oleh Mbah Wo Kucing membuahkan hasil, banyak anak-anak di Desa Kauman ketika itu yang masuk dan ingin mempelajari Reog Ponorogo dibawah paguyuban Pujangga Anom. Seluruh biaya pengeluaran paguyuban Pujangga Anom berasal dari keuangan Mbah Wo Kucing pribadi dan tidak menyusahkan kondisi keuangan keluarganya.

Awal berdirinya paguyuban Pujangga Anom di ikuti oleh sekitar 54 anak-anak di Desa Kauman pada tahun 1965 dan beberapa orang tua mereka rela untuk bergabung menjadi bagian dari paguyuban Pujangga Anom. Beberapa orang tua anak tersebut menjadi penabuh alat musik dan membantu Mbah Wo Kucing dalam memberikan gerakan koreografi Kesenian Reog Ponorogo. Paguyuban Pujangga anom menjadi grup Reog kebanggaan Desa Kauman dan Kabupaten Ponorogo pada waktu itu. Hegemoni masyarakat terhadap Kesenian Reog Ponorogo pada waktu itu menjadikan paguyuban Pujangga Anom menjadi barometer utama untuk kelompok paguyuban Reog Ponorogo.

Perkembangan yang begitu pesat membuat paguyuban Pujangga Anom mendapatkan banyak tawaran pekerjaan 
untuk mengisi acara baik yang bersifat resmi maupun tidak resmi. Kegiatan bersifat remi antara lain menjadi pengisi acara dalam kegiatan Pemerintah Daerah Kabupaten Ponorogo, mendapatkan undangan dari Kabupaten lain di Pulau Jawa, dan beberapa personil paguyuban Pujangga Anom menjadi juri dalam perlombaan Reog Ponorogo. Adapun kegiatan yang bersifat tidak resmi adalah kegiatan bersih desa, pengisi hiburan pada pesta pernikahan, dll. Berdasarkan kegiatan-kegiatan tersebut mampu membuat para personil paguyuban Pujangga Anom memiliki penghasilan dan sebagian uang digunakan untuk perawatan peralatan dan membeli kostum untuk anak-anak menari.

Mulai saat itu paguyuban Pujangga Anom memiliki kemandirian dalam hal keuangan dan perekonomian yang dulu masih ditanggung sepenuhnya oleh Mbah Wo Kucing. Mbah Wo Kucing dalam setiap pertemuan latihan selalu mengajarkan gerakan sesuai dengan karakter masing-masing dari Prabu Klono Sewandono, Patih Pujangga Anom, penari Jathil, dan Singo Barong (Barongan+Dhadhak Merak). Khusus untuk penari barongan, Mbah Wo Kucing mengajarkan gerakan-gerakannya harus sama seperti hewan aslinya yaitu harimau. Mulai dari gerakan leher, gerakan tubuh, sampai dengan gerakan dhadak meraknya harus menyerupai hewan aslinya.

Adapun nama-nama jogetan yang dimiliki oleh paguyuban Pujangga Anom adalah jogetan kiprah untuk tokoh Prabu Klono Sewandono, jogetan patih untuk tokoh Pujangga Anom, jogetan Jathil untuk tokoh pasukan berkuda, jogetan dhadak merak untuk tokoh Singo Barong, jogetan krawit untuk pengiring dan penabuh alat musik, dan jogetan warok untuk tokoh warok sebagai pengawal dan pagar betis keamanan iring-iringan paguyuban Pujangga Anom.

Prestasi Mbah Wo Kucing dalam mengembangkan, melestarikan, dan memperkenalkan Kesenian Reog Ponorogo adalah mewakili Indonesia untuk memperkenalkan budaya Ponorogo di Amerika Serikat sebanyak tiga kali dimulai pada tahun 1994, menjadi ketua pendadaran juri Festival Reog Ponorogo tahun 1996, menjadi tokoh Ponorogo yang sering mendapatkan panggilan ke Jakarta untuk memperkenalkan Reog Ponorogo, merintis berkembangnya Kesenian Reog Ponorogo di Kabupaten Wonogiri bersama dengan Bupati Wonogiri Begug Purnomo Sihdi, dan masih banyak lagi penghargaan individu yang dimiliki oleh Mbah Wo Kucing. Mbah Wo Kucing banyak melahirkan seniman-seniman Reog Ponorogo yang sekarang masih melesarikan kesenian tersebut. 
Warok adalah seseorang yang memiliki tingkat sprititual yang tinggi dan memiliki kedekatan hubungan antara Tuhan Yang Maha Esa dengan makhluknya. Warok ada dua jenis yaitu Warok Tua dan Warok Muda. Warok Tua adalah seorang tokoh pengayom dan menjadi panutan dari masyarakat, sedangkan Warok Muda adalah seseorang yang masih dalam taraf untuk menuntut ilmu.

Mbah Wo Kucing adalah seorang Warok Tua yang memiliki banyak murid bahkan sampai di luar Kabupaten dan Propinsi Jawa Timur. Mbah Wo Kucing sangat berpengalaman dan sangat senang apabila ilmu yang dia miliki dibagikan kepada orang-orang yang ingin menjadi seorang Warok. Namun itu hanya terjadi jauh pada saat generasi Warok Ponorogo masih ada.

Sifat-sifat lain yang dimiliki oleh seorang Mbaah Wo Kucing sebagai Warok Ponorogo adalah Bares Ures Cablaka yang artinya adalah ketika berbicara sesuatu tidak berbohong dan apa adanya. Keberadaan Warok Ponorogo memang banyak yang tidak mengetahui karena para Warok Ponorogo tidak senang apabila mengumbar kemampuan dan kelebihannya di depan umum. Warok merupakan sifat seseorang yang suka menolong, suka berbagi pengetahuan kepada siapa saja tanpa pamrih, dan menjadi panutan bagi masyarakat sekitarnya. Sifat yang sama seperti yang dipegang teguh oleh Mbah Wo Kucing selama ini ketika melestarikan budaya khas Kabupaten Ponorogo yaitu Warok Ponorogo.

Adapun nama-nama bagian dari pakaian yang dikenakan Warok Ponorogo ketika itu antara lain Udeng Gadhung warna hitam, Baju luar penadhon hitam polos, memakai kaos kimplong bagian dalam (kaos sport), sabuk othog yang dipakai dipinggang Warok, usus-usus putih atau kolor tapi tidak besar ukurannya, gelang akar karu yang dipakai Warok ditangan, memakai celana kombor (kathog kombor maro kenthol), dan memakai sandal dari kulit sapi. Mbah Wo Kucing selalu memakai pakaian tersebut ketika menghadiri suatu kegiatan seni maupun kegiatan sehari-hari. Hal itu disebabkan karena baju tersebut sangat memudahkan Mbah Wo Kucing dalam bergerak dan tidak membutuhkan waktu yang lamaa untuk memakainya.

Fungsi utama dari Warok Ponorogo adalah sebagai kelompok keamanan yang menjaga keamanan dan ketertiban desa. Fungsi lain adalah sebagai ketua dari paguyuban Reog Ponorogo, sebagai guru dalam mengolah ilmu kanuragan dan kebatian, menjadi tokok yang netral dalam menyelesaikan berbagai masalah, dan yang terpenting 
adalah sebagai pemangku adat desa setempat.

\section{Kehidupan seorang Warok} Ponorogo tidak lepas dari keberadaaan seorang Gemblak. Gemblak adalah seorang anak kecil berumur 10-13 tahun yang memiliki ciri fisik yang tampan, kulit bersih, dan memuliki tubuh yang lemah gemulai seperti perempuan.

Fungsi daripada Gemblak adalah sebagai kongkonan atau suruhan Warok Ponorogo dan selalu mendampingi Warok kemanapun dia pergi. Seorang Gemblak didapatkan seorang Warok dengan cara meminta izin kepada orang tua anak tersebut untuk dipelihara dan dirawat serta tidak jarang untuk disekolahkan oleh Warok tersebut.

Imbalan dari pekerjaan seorang Gemblak yaitu seekor anak sapi dalam jangka waktu satu sampai dua tahun, tergantung dari perjanjian yang telah dibuat. Apabila disamakan dengan harga sekarang berkisar antara delapan juta rupiah sampai sepuluh juta rupiah per tahun. Memang pada saat itu Gemblak masih menjadi tradisi dan kebiasaan bagi masyarakat Ponorogo khususnya seorang Warok. Hal itu disebabkan karena ada ilmu yang memiliki pantangan untuk berhubungan tubuh dengan wanita atau istrinya.

Kewajiban seorang Warok adalah membayar upah, memelihara, dan merawatnya sampai tumbuh dewasa
Gemblak tersebut. Apabila Gemblak sudah memasuki usia dewasa, maka Gemblak tersebut akan dikembalikan kepada orang tua kandungnya dan Warok akan mencari Gemblak yang lainnya.

Disisi lain pandangan negatif tentang seorang Gemblak ternyata tidak benar. Gemblak itu bisa diibaratkan sebagai anak asuh atau anak adopsi namun dengan jangka waktu yang sudah disepakati. Seorang Warok apabila memiliki seorang Gemblak maka akan berimbas kepada status sosial yang ia miliki di masyarakat. Namun lebih lanjut Kasmiati mengungkapkan bahwa Gemblak bukanlah pasangan dari seorang Warok. Hal itu dibuktikan dengan pernikahan yang terjadi antara Mbah Wo Kucing dengan Kasmiati yang dikaruniai tiga orang anak. Dahulu Gemblak yang dimiliki oleh Mbah Wo Kucing selalu diajak untuk menghadiri perkumpulan Warok Ponorogo dalam suatu acara. Perkumpulan Warok tersebut dilakukan di rumah para Warok secara bergiliran setiap tahunnya. Dengan adanya perkumpulan tersebut, para Warok memamerkan Gemblak yang dimiliknya di depan Warok lain. Selain itu Gemblak juga dapat disuruh oleh Warok ketika membutuhkan bantuan. Perkembangan tradisi Gemblakan di Kabupaten Ponorogo berakhir tahun 1980-an. Masyarakat Ponorogo sudah 
tidak melakukan kebiasaan itu termasuk para Warok

\section{Pembahasan}

Mbah Wo Kucing adalah salah satu sesepuh seniman Reog Ponorogo sekaligus sesepuh Warok Ponorogo yang ada di Kabupaten Ponorogo. Mbah Wo Kucing memiliki nama asli yaitu Kasni Gunopati. Beliau lahir pada 30 Juni 1934 di Desa Kauman Kecamatan Kauman Kabupaten Ponorogo. Ciri Fisik Kasni Gunopati yaitu bertubuh tinggi kurus, memiliki kumis dan jenggot yang panjang berwarna putih, berperawakan tegap layaknya seorang Warok dan juga selalu memakai celana kombor (Kathok Kombor Maro Kentol) khas masyarakat Kabupaten Ponorogo waktu itu. Kasni Gunopati atau Mbah Wo Kucing memiliki badan kurus namun kekuatan fisik beliau diatas rata-rata orang biasa, hal itu disebabkan karena Kasni Gunopati dahulu adalah pemain sepak bola dan sering menjaga kesehatan tubuh dengan berolahraga

Berbanding lurus dengan ciri fisiknya, Kasni Gunopati juga mempunyai ciri kepribadian yang sangat berwibawa dihormati oleh semua orang yang bertemu dengan beliau, mengayomi keluarga dan masyarakat sekitar, selalu menjalankan tirakat untuk mencapai tingkat tertinggi dalam spiritualnya, selalu berbicara jujur, tidak suka berbohong, kalem dan ramah kepada siapa saja, bersahaja, dan sebagai sesepuh dan pini sepuh Desa Kauman, Kasni Gunopati adalah pengayom masyarakat dan menjadi tokoh penengah apabila terdapat konflik.

Menurut cerita yang berkembang pada masyarakat sekitar tempat tinggal Kasni Gunopati dan para teman seangkatan maupun seprofesi dengan beliau sebagai seniman Reog Ponorogo, istilah "Kucing" yang tersemat pada Kasni Gunopati atau Mbah Wo Kucing merujuk pada sifat seekor kucing yang sangat gesit dan sangat sulit untuk ditangkap. Kasni Gunopati bermain judi, apabila terjadi penggrebegkan oleh aparat keamanan, beliau sangat sulit untuk ditangkap dan bahkan tidak ada yang berani menangkapnya. Selain itu ketika beliau sedang bermain kartu remi, dalam suatu suasana beliau mengatakan, "Iki mesti kucing!!!" sambil membanting kartunya dan selalu kartu yang dibanting itu sesuai dengan keinginannya sehingga Mbah Wo sering menang dalam permainan. Dengan julukan Mbah Wo Kucing inilah yang membuat Kasni Gunapati lebih terkenal namanya karena mudah diingat oleh masyarakat. Pada hari Rabu Pon tanggal 13 Agustus 2008 Mbah Wo Kucing menghembuskan nafas terakhirnya dan meninggal dunia.

Awal mula Mbah Wo Kucing terjun menjadi seorang seniman Reog Ponorogo ketika Mbah Wo Kucing benar-benar ingin memulai semua hal tentang pelestarian kesenian Reog Ponorogo mulai dari titik nol. 
Perjalanan untuk melestarikan kesenian Reog Ponorogo dilakukannya sedikit-demi sedikit dengan cara menyisihkan beberapa penghasilan dari tanah bengkok gaji sebagai perangakat Desa Kauman yaitu Kamituwo dan gaji menjadi Mandor perkebunan tebu yang membawahi tiga Kecamatan di Kabupaten Ponorogo. Biaya hasil dari menyisihkan penghasilannya beliau gunakan untuk membeli perlengkapan alat musik karawitan kesenian Reog Ponorogo secara bertahap.

Usaha untuk melestarikan kesenian Reog Ponorogo tersebut maka Mbah Wo Kucing membeli alat musik untuk paguyuban Reog Ponorogo miliknya yaitu dengan membeli barongan beserta dhadak merak sejumlah satu buah. Beberapa bulan kemudian Mbah Wo Kucing membeli kendang sekaligus ketipung atau kendang terusan. Mbah Wo Kucing kemudian membeli slompret (terompet), angklung, dan kenong. Peralatan untuk kesenian Reog Ponorogo sudah dimiliki Mbah Wo Kucing, Namun beliau belum mampu membeli kepala harimau atau barongan beserta dhadak merak satu lagi agar pembelajaran dan latihan kesenian Reog Ponorogo menjadi maksimal.

Pada tahun 1965 Mbah Wo Kucing mampu membeli satu dhadak merak lagi sekaligus membeli Gong yang berasal dari hasil mengumpulkan uang sedikit-demi sedikit. Perlengkapan untuk kesenian Reog Ponorogo sudah lengkap, kemudian beliau mencari seseorang yang nantinya akan ditugaskan untuk merawat seluruh perlengkapan Reog Ponorogo tersebut sehingga bisa awet dan tahan lama. Mbah Wo Kucing menunjuk seseorang pemuda di Desa Kauman yang bernama Daman. Daman adalah seorang remaja pada waktu itu yang tinggal di Desa Kauman dan selalu bersamasama Mbah Wo Kucing sebagai asisten.

Memasuki tahun 1966 dimulailah usaha Mbah Wo Kucing untuk melestarikan Kesenian Reog Ponorogo di Desa Kauman. Paguyuban tersebut diberi nama Pujangga Anom. Pemilihan nama Pujangga Anom sendiri tidak lepas dari tokoh legenda Kerajaan Bantarangin yaitu Pujangga Anom yang merupakan pengawal setia Prabu Klono Sewandono dan memiliki kelebihan di bidang seni. Mbah Wo Kucing turun langsung ke rumah-rumah masyarakat Desa Kauman untuk memperkenalkan paguyuban tersebut supaya banyak anak-anak di Desa Kauman yang tertarik untuk mempelajari Kesenian Reog Ponorogo.

Usaha yang tak kenal lelah yang dilakukan oleh Mbah Wo Kucing membuahkan hasil, banyak anak-anak di Desa Kauman ketika itu yang masuk dan ingin mempelajari Reog Ponorogo dibawah paguyuban Pujangga Anom. Seluruh biaya pengeluaran paguyuban Pujangga Anom berasal dari keuangan Mbah Wo Kucing pribadi dan tidak menyusahkan kondisi keuangan keluarganya. 
Awal berdirinya paguyuban Pujangga Anom di ikuti oleh sekitar 54 anak-anak di Desa Kauman pada tahun 1965 dan beberapa orang tua mereka rela untuk bergabung menjadi bagian dari paguyuban Pujangga Anom. Beberapa orang tua anak tersebut menjadi penabuh alat musik dan membantu Mbah Wo Kucing dalam memberikan gerakan koreografi Kesenian Reog Ponorogo. Paguyuban Pujangga anom menjadi grup Reog kebanggaan Desa Kauman dan Kabupaten Ponorogo pada waktu itu. Hegemoni masyarakat terhadap Kesenian Reog Ponorogo pada waktu itu menjadikan paguyuban Pujangga Anom menjadi barometer utama untuk kelompok paguyuban Reog Ponorogo.

Perkembangan yang begitu pesat membuat paguyuban Pujangga Anom mendapatkan banyak tawaran pekerjaan untuk mengisi acara baik yang bersifat resmi maupun tidak resmi. Kegiatan bersifat remi antara lain menjadi pengisi acara dalam kegiatan Pemerintah Daerah Kabupaten Ponorogo, mendapatkan undangan dari Kabupaten lain di Pulau Jawa, dan beberapa personil paguyuban Pujangga Anom menjadi juri dalam perlombaan Reog Ponorogo. Adapun kegiatan yang bersifat tidak resmi adalah kegiatan bersih desa, pengisi hiburan pada pesta pernikahan, dll. Berdasarkan kegiatan-kegiatan tersebut mampu membuat para personil paguyuban
Pujangga Anom memiliki penghasilan dan sebagian uang digunakan untuk perawatan peralatan dan membeli kostum untuk anakanak menari.

Mulai saat itu paguyuban Pujangga Anom memiliki kemandirian dalam hal keuangan dan perekonomian yang dulu masih ditanggung sepenuhnya oleh Mbah Wo Kucing. Mbah Wo Kucing dalam setiap pertemuan latihan selalu mengajarkan gerakan sesuai dengan karakter masingmasing dari Prabu Klono Sewandono, Patih Pujangga Anom, penari Jathil, dan Singo Barong (Barongan+Dhadhak Merak). Khusus untuk penari barongan, Mbah Wo Kucing mengajarkan gerakan-gerakannya harus sama seperti hewan aslinya yaitu harimau. Mulai dari gerakan leher, gerakan tubuh, sampai dengan gerakan dhadak meraknya harus menyerupai hewan aslinya. Prestasi Mbah Wo Kucing dalam mengembangkan, melestarikan, dan memperkenalkan Kesenian Reog Ponorogo adalah mewakili Indonesia untuk memperkenalkan budaya Ponorogo di Amerika Serikat sebanyak tiga kali dimulai pada tahun 1994, menjadi ketua pendadaran juri Festival Reog Ponorogo tahun 1996, menjadi tokoh Ponorogo yang sering mendapatkan panggilan ke Jakarta untuk memperkenalkan Reog Ponorogo, merintis berkembangnya Kesenian Reog Ponorogo di Kabupaten Wonogiri bersama dengan Bupati Wonogiri Begug Purnomo Sihdi, dan masih banyak lagi penghargaan 
individu yang dimiliki oleh Mbah Wo Kucing. Mbah Wo Kucing banyak melahirkan seniman-seniman Reog Ponorogo yang sekarang masih melesarikan kesenian tersebut.

Beberapa peninggalan peralatan Reog Ponorogo dari almarhum Mbah Wo Kucing adalah dua dhadhak merak dan kepala barongan, sepasang kendang dan kendang terusan (ketipung), satu set Gong, satu set angklung, dan satu slompret atau terompet yang sampai sekarang masih awet karena dirawat oleh Daman.

Warok adalah seseorang yang memiliki tingkat sprititual yang tinggi dan memiliki kedekatan hubungan antara Tuhan Yang Maha Esa dengan makhluknya. Mbah Wo Kucing sangat berpengalaman dan sangat senang apabila ilmu yang dia miliki dibagikan kepada orang-orang yang ingin menjadi seorang Warok. Namun itu hanya terjadi jauh pada saat generasi Warok Ponorogo masih ada. Sifat-sifat lain yang dimiliki oleh seorang Mbaah Wo Kucing sebagai Warok Ponorogo adalah Bares Ures Cablaka yang artinya adalah ketika berbicara sesuatu tidak berbohong dan apa adanya. Keberadaan Warok Ponorogo memang banyak yang tidak mengetahui karena para Warok Ponorogo tidak senang apabila mengumbar kemampuan dan kelebihannya di depan umum.

Adapun nama-nama bagian dari pakaian yang dikenakan Warok Ponorogo ketika itu antara lain Udeng Gadhung warna hitam, Baju luar penadhon hitam polos, memakai kaos kimplong bagian dalam (kaos sport), sabuk othog yang dipakai dipinggang Warok, usus-usus putih atau kolor tapi tidak besar ukurannya, gelang akar karu yang dipakai Warok ditangan, memakai celana kombor (kathog kombor maro kenthol), dan memakai sandal dari kulit sapi. Mbah Wo Kucing selalu memakai pakaian tersebut ketika menghadiri suatu kegiatan seni maupun kegiatan sehari-hari. Hal itu disebabkan karena baju tersebut sangat memudahkan Mbah Wo Kucing dalam bergerak dan tidak membutuhkan waktu yang lamaa untuk memakainya.

Fungsi utama dari Warok Ponorogo adalah sebagai kelompok keamanan yang menjaga keamanan dan ketertiban desa. Fungsi lain adalah sebagai ketua dari paguyuban Reog Ponorogo, sebagai guru dalam mengolah ilmu kanuragan dan kebatian, menjadi tokok yang netral dalam menyelesaikan berbagai masalah, dan yang terpenting adalah sebagai pemangku adat desa setempat.

Dalam hal ini pantas jika Mbah Wo Kucing mendapatkan gelar Warok Ponorogo, hal itu dikarenakan atas jasa dan dedikasinya yang tinggi dalam melestarikan budaya lokal yaitu Reog Ponorogo dan tetap menjalankan hidup dengan tuntunan sebagai seorang Warok Ponorogo. Tidak banyak masyarakat Kabupaten Ponorogo yang tetap mempertahankan tradisi di dalam perkembangan globalisasi seperti 
saat ini. Mbah Wo Kucing meyakini bahwa dengan tetap memegang teguh tradisi khas Kabupaten Ponorogo ini maka beliau akan bisa melestarikan harta berharga yang sudah sejak lama menjadi warisan budaya masyarakat Kabupaten Ponorogo yang akan selalu dilestarikan keberadaannya oleh masyarakat Kabupaten Ponorogo.

\section{Penutup}

\section{A. Kesimpulan}

Berkembangnya kebudayaan disuatu daerah disebabkan karena adanya campur tangan dari masyarakat yang peduli untuk tetap melestarikan kebudayaan tersebut agar bisa dinikmati oleh generasi berikutnya. Tidak terkecuali berkembangnya kebudayaan di Kabupaten Ponorogo yang menjadi ciri khas kebudayaan setempat mendapatkan campur tangan dari Kasni Gunopati atau Mbah Wo Kucing. Kasni Gunopati atau Mbah Wo Kucing adalah salah satu seniman Kesenian Reog Ponorogo yang memiliki pengaruh di Kabupaten Ponorogo. Kasni Gunopati merupakan seniman asli dari Kabupaten Ponorogo yang lahir pada 30 Juni 1934 di Desa Kauman Kecamatan Kauman Kabupaten Ponorogo. Kasni Gunopati merupakan anak pertama dari empat bersaudara putra dari pasangan Martorejo dan Sutilah.

Keselarasan antara Warok Ponorogo dan Kesenian Reog Ponorogo merupakan satu kesatuan yang tidak bisa dipisahkan serta memiliki fungsi yang saling melengkapi. Warok Ponorogo juga dapat disebut seniman Reog Ponorogo karena hampir semua Warok Ponorogo memiliki Paguyuban Reog Ponorogo sendiri. Seperti halnya Mbah Wo Kucing sebagai pimpinan Paguyuban Reog Ponorogo, hampir setiap Warok Ponorogo di Kabupaten Ponorogo juga menjadi pemimpin paguyuban. Warok Ponorogo memiliki kepekaan spiritual dan kepekaan seni yang tinggi, sehingga Warok Ponorogo mampu untuk mengajarkan kepada anak didiknya gerakan-gerakan Kesenian Reog Ponorogo dengan begitu baik berikut dengan nilai filosofi yang terkandung dalam setiap gerakan. Peranan Mbah Wo Kucing dalam menjaga dan melestarikan Kesenian Reog Ponorogo dan posisinya sebagai Warok Ponorogo menjadikan beliau sebagai panutan bagi senimanseniman muda yang ada di Kabupaten Ponorogo.

Peran Mbah Wo Kucing dalam melestarikan Kesenian Reog Ponorogo di Desa Kauman. Mbah Wo Kucing mendirikan sebuah Paguyuban Reog Ponorogo. Paguyuban tersebut diberi nama Pujangga Anom. Pemilihan nama Pujangga Anom sendiri tidak lepas dari tokoh legenda Kerajaan Bantarangin yaitu Pujangga Anom yang merupakan pengawal setia Prabu Klono Sewandono dan memiliki kelebihan di bidang seni. 
Mbah Wo Kucing dalam setiap pertemuan latihan selalu mengajarkan gerakan sesuai dengan karakter masingmasing dari Prabu Klono Sewandono, Patih Pujangga Anom, penari Jathil, dan Singo Barong (Barongan+Dhadhak Merak). Khusus untuk penari barongan, Mbah Wo Kucing mengajarkan gerakangerakannya harus sama seperti hewan aslinya yaitu harimau. Mulai dari gerakan leher, gerakan tubuh, sampai dengan gerakan dhadak meraknya harus menyerupai hewan aslinya. Mbah Wo Kucing menerapkan sistem disiplin yang luar biasa kepada anak didiknya. Hal itu dimaksudkan agar anak didiknya nanti mampu melestarikan hal-hal yang telah diajarkan oleh Mbah Wo Kucing.

Adapun nama-nama jogetan yang dimiliki oleh paguyuban Pujangga Anom adalah jogetan kiprah untuk tokoh Prabu Klono Sewandono, jogetan patih untuk tokoh Pujangga Anom, jogetan Jathil untuk tokoh pasukan berkuda, jogetan dhadak merak untuk tokoh Singo Barong, jogetan krawit untuk pengiring dan penabuh alat musik, dan jogetan warok untuk tokoh warok sebagai pengawal dan pagar betis keamanan iring-iringan paguyuban Pujangga Anom.

Prestasi Mbah Wo Kucing dalam mengembangkan, melestarikan, dan memperkenalkan Kesenian Reog Ponorogo adalah mewakili Indonesia untuk memperkenalkan budaya
Ponorogo di Amerika Serikat sebanyak tiga kali dimulai pada tahun 1994, menjadi ketua pendadaran juri Festival Reog Ponorogo tahun 1996, menjadi tokoh Ponorogo yang sering mendapatkan panggilan ke Jakarta untuk memperkenalkan Reog Ponorogo, dan masih banyak lagi penghargaan individu yang dimiliki oleh Mbah Wo Kucing.

\section{B. Saran}

Kasni Gunapati atau Mbah Wo Kucing merupakan salah satu sesepuh seniman Reog Ponorogo yang memiliki dedikasi yang tinggi dalam mengembangkan dan melestarikan Kesenian Reog Ponorogo dan mempertahankan filosofi Warok Ponorogo sebagai pegangan hidupnya. Hal itu bertujuan agar budaya lokal yang menjadi ciri khas masyarakat Kabupaten Ponorogo tidak hilang tergerus oleh perkembangan arus globalisasi yang begitu pesat. Meskipun Kasni Gunapati atau Mbah Wo Kucing sudah meninggal dunia, namun banyak sekali murid-murid beliau dulu yang saat ini masih berusaha untuk mengembangkan dan melestarikan budaya lokal Kabupaten Ponorogo agar tidak punah. regenerasi ini diharapkan mampu menjadi mata rantai yang tidak akan pernah terputus dan akan selalu menjadi kebanggaan masyarakat Kabupaten Ponorogo.

Peneliti juga berkeinginan menyuguhkan harapan serta saran 
tertentu, adapun saran-saran yang dapat peneliti kemukakan adalah sebagai berikut:

1. Bagi Pemerintah Daerah Kabupaten Ponorogo

Diharapkan pihak pemerintah agar tetap dapat melestarikan Kesenian budaya lokal yang terwujud dalam Kesenian Reog Ponorogo dan Warok Ponorogo sebagai salah satu peninggalan peradapan sosial masyarakat Kabupaten Ponorogo yang menjadi sebuah ciri Khas yang menjadi kebanggaan Kabupaten Ponorogo dalam taraf nasional maupun internasional. Pemerintah Kabupaten Ponorogo juga diharapkan untuk memperhatikan, mendukung, dan memberikan bantuan kepada seniman-seniman Reog Ponorogo yang saat ini masih ada agar Reog Ponorogo sebagai ciri khas Kabupaten Ponorogo tetap lestari sampai kelak nanti. Disamping itu diharapkan juga Pemerintah Daerah Kabupaten Ponorogo juga mewadahi kreatifitas para seniman melalui perlombaan Kesenian Reog Ponorogo agar para seniman terpacu untuk mengembangkan Kesenian Reog Ponorogo dari masa ke masa.

2. Bagi Masyarakat Kabupaten Ponorogo Kepada masyarakat diharapkan memiliki kesadaran dan kepedulian untuk tetap melestarikan
Kesenian Reog Ponorogo dan Warok Ponorogo sebagai salah satu wujud dan komitmen untuk menjaga kelestarian budaya yang sudah lama menjadi kebanggaan masyarakat Kabupaten Ponorogo.

\section{DAFTAR PUSTAKA}

Abraham Nurcahyo, dkk. 2009. Ilmu Sosial dan Budaya Dasar. Madiun: LESwastika Press

Andre Atta Ujan. 2009. Multikulturalisme Belajar Hidup Bersama dalam Perbedaan. Jakarta: Indeks

Anidal Hasjir, dkk. 1984. Kamus Istilah Sosiologi. Jakarta: Balai Pustaka.

Badan Pusat Statistik Kabupaten Ponorogo. 2013. Ponorogo dalam Angka 2013. Ponorogo: BPS Kabupaten Ponorogo. Bambang Marhijanto. 1995. Kamus Bahasa Indonesia Populer. Surabaya: Bintang Timur Surabaya

Basrowi dan Suwandi. 2008. Memahami Penelitian Kualitatif. Jakarta: Rineka Cipta.

Burhan Bungin. 2007. Penelitian Kualitatif: Komunikasi, Ekonomi, Kebijakan Publik, dan Ilmu Sosial. Jakarta: Kencana.

Cholid Narbuko dan Abu Achmadi. 2003. Metodologi Penelitian. Jakarta: Bumi Aksara.

Elly M. Setiadi, dkk. Ilmu Sosial dan Budaya Dasar. Jakarta: Kencana. 
Emzir. 2011. Metodologi Penelitian Kualitatif

Analisis Data. Jakarta: Raja Grafindo Persada.

Hadi Sabari Yunus. 2010. Metodologi Penelitian Wilayah Kontemporer. Yogyakarta: Pustaka Belajar.

H.B. Sutopo. 2006. Metodologi Penelitian Kualitatif Dasar Teori dan Terapannya Dalam Penelitian. Surakarta: Universitas Sebelas Maret.

Herry Lisbijanto. 2013. Reog Ponorogo. Yogyakarta: Graha Ilmu.

Husaini Usman dan Purnomo Setiady Akbar. 2004. Metodologi Penelitian Sosial. Jakarta: Bumi Aksara.

Koentjaraningrat. 2009. Pengantar Ilmu Antropologi. Jakarta: Rineka Cipta.

Lexy J. Moleong. 2007. Metodologi Penelitian Kuallitatif. Bandung: PT Remaja Rosdakarya.

Maryaeni. 2008. Metode Penelitian Kebudayaan. Jakarta: Bumi Aksara.

Milles Matthew. B dan A. Michael Huberman. 1992. Analisis Data Kualitatif. Jakarta: Universitas Indonesia.

Nasution. 2004. Metode Research: Penelitian Ilmiah. Jakarta: Bumi Aksara.
Nooryan Bahari. 2008. Kritik Seni: Wacana, Apresiasi dan Kreasi. Yogyakarta: Pustaka Belajar.

Nyoman Kutha Ratna. 2010. Metodologi Penelitian: Kajian Budaya dan IlmuIlmu Sosial Humaniora pada Umumnya. Yogyakarta: Pustaka Belajar.

Purwadi. 2005. Babad Majapahit. Yogyakarta: Media Abadi.

Purwowijoyo.1990. Babad Ponorogo Jilid VII Ponorogo Zaman Belanda. Ponorogo: Dinas Pariwisata dan Seni Budaya Kabupaten Ponorogo.

Pusat Pembinaan dan Pengembangan Bahasa. 1991. Kamus Besar Bahasa Indonesia. Jakarta: Balai Pustaka.

Rafael Raga Maran. 2000. Manusia dan Kebudayaan dalam Perspektif Ilmu Budaya Dasar. Jakarta: Rineka Cipta. Rusli Lutan. 2001. Keniscayaan Pluralitas Budaya Daerah. Bandung: Angkasa.

Sulasman \& Setia Gumilar. 2013. Teori-Teori Kebudayaan: dari Teori hingga Aplikasi. Bandung: Pustaka Setia.

Soerjono Soekanto. 2012. Sosiologi Suatu Pengantar. Jakarta: Rajawali Pers.

Sugiyono. 2011. Metode Penelitian Pendidikan: Pendekatan Kualitatif, Kuantitatif, dan $R \& D$. Bandung: Alfabeta.

Suharsimi Arikunto. 2010. Prosedur Penelitian: Suatu Pendekatan Praktik. Jakarta: Rineka Cipta. 
Uhar Suharsaputra. 2012. Metode Penelitian:

Kuantitatif, Kualitatif, dan Tindakan.

Bandung: PT Refika Aditama.

Uswatun Hasanah. 2014. Teater Tradisional

Berbasis Reyog Ponorogo. Wonogiri:

UNS

Warsito. 2012. Antropologi Budaya.

Yogyakarta: Ombak 